\title{
Path Analysis on the Factors Affecting Postnatal Depression
}

\author{
Sri Widarti',2), Uki Retno Budihastuti3), Vitri Widyaningsih4) \\ ${ }^{1)}$ Midwifery Academy Nyai Ahmad Dahlan, Yogyakarta \\ 2)Masters Program in Public Health, Universitas Sebelas Maret \\ 3)Department of Obstetrics and Gynecology, Dr Moewardi Hospital \\ 4)Faculty of Medicine, Universitas Sebelas Maret
}

\begin{abstract}
Background: Postpartum depression is one of the emotional disorders as a result of failure to accept the psychological adaptation process in women in the postpartum period. There are many factors of postpartum depression. This study aimd to determine factors affecting postpartum depression.

Subjects and Method: This was a cross sectional study conducted at 30 villages, in Bantul, Yogyakarta, from February to March 2019. A sample of 210 postaprtum mothers was selected by purposive sampling. The dependent variable was the postpartum depression. The independent variables were age, education, income, ANC visit, number of children, parity, unwanted pregnancy, type of labor, family support, domestic violence, and stress. Postpartum depression was measured by Endinburgh postnatal depression scale. Psychological stress was measured by Kessler psychological distress scale. The other variables were collected by questionnaire. The data was analyzed by path analysis.

Results: Postpartum depression was directly and positively affected by type of labor $(\mathrm{b}=3.85$; $95 \% \mathrm{CI}=0.16$ to $7.54 ; \mathrm{p}=0.041)$, stress $(\mathrm{b}=3.53 ; 95 \% \mathrm{CI}=0.34$ to $6.72 ; \mathrm{p}=0.030)$, parity $(\mathrm{b}=4.01$; $95 \% \mathrm{CI}=0.04$ to $7.98 ; \mathrm{p}=0.048)$, unwanted pregnancy $(\mathrm{b}=9.43 ; 95 \% \mathrm{CI}=1.51$ to $17.3 ; \mathrm{p}=0.019)$. It was directly and negatively affected by number of children $(\mathrm{b}=-5.05 ; 95 \% \mathrm{CI}=-10$ to $-0.02 ; \mathrm{p}=$ o.049), family support $(b=-3.73 ; 95 \% \mathrm{CI}=-6.98$ to $-0.50 ; \mathrm{p}=0.024)$, and ANC visit $(\mathrm{b}=-8.18 ; 95 \%$ $\mathrm{CI}=-15.3$ to $-1.00 ; \mathrm{p}=0.026)$. Postpartum depression was indirectly affected by education, income, domestic violence, and age.

Conclusion: Postpartum depression is directly and positively affected by type of labor, stress, parity, unwanted pregnancy. It is directly and negatively affected by number of children, family support, and ANC visit. Postpartum depression is indirectly affected by education, income, domestic violence, and age.
\end{abstract}

Keywords: Postpartum depression, domestic violence, path analysis

\section{Correspondence:}

Sri Widarti. Masters Program in Public Health, Universitas Sebelas Maret. Jl. Ir. Sutami 36A, Surakarta 57126, Central Java. Email: widacorset@gmail.com.Mobile: 082135814923.

\section{BACKGROUND}

Postpartum is a period characterized by a heavy burden on the mother, especially impaired affective abilities (Sylvé et al., 2017). After the delivery process the mother will experience physical and psychological changes. Mother's change is usually seen as a positive experience for a woman, it still requires easy physical, psychological and social adaptation (Habel et al., 2016).
During the postpartum period, mood disorders are common in women, where nearly $85 \%$ of new mothers experience mood disorders, with $10-15 \%$ of women experiencing significant clinical symptoms (Sylvé et al., 2017). The prevalence of postpartum depression in countries with lower middle income is from $1.9 \%$ to $82.1 \%$ and in high-income countries is from $5.2 \%$ to $74 \%$ (Tikmani et al., 2016). 
Social support includes 4 main dimensions, namely information, material, emotional, and partner. These aspects of support will support the mental health of postpartum mothers (Manley, 2013). External aspects are family support, husband support, culture or community habits, economic status, information on postpartum care, and a history of postpartum care. Poor marital relations, prenatal depression, child hood illness, low socioeconomic status, low education level, unwanted pregnancy, obesity, previous postpartum depression, and complications during pregnancy are determinants of postpartum depression (Tikmani et al., 2016). Higher levels of depression are evident in pregnant and postpartum women who are socially and economically disadvantaged (Stepanikova,2017).

Postpartum depression can have a negative impact on maternal, child and family health. In mothers who experience postpartum depression, interest, and awareness of their babies is lacking. Mothers often do not respond positively to their babies such as crying, eye gaze or gestures. As a result, mothers who experience postpartum depression are not able to care for their babies optimally, including lazy to give breast milk to their babies. This also has a negative impact on children's physical, social and cognitive development (Nonacs, 2014).

\section{SUBJECTS AND METHOD \\ a. Study Design \\ This was a cross sectional study conducted at 30 villages in Bantul, Yogyakarta, from March to April 2019.}

\section{b. Population and Sample}

The target population of this study was postpartum mothers in the first week to the sixth week in Bantul Regency, Yogyakarta. The sampling technique in this study was proportional random sampling to get 210 postpartum mothers.

\section{c. Study Variables}

The dependent variable in the study was postpartum depression. The independent variables were age, education, family income, number of antenatal care, number of families, parity, unwanted pregnancy, labor type, family support, domestic violence, and psychological stress.

\section{d. Operational Definition of Variables}

Postpartum depression is a disorder of psychological adaptation that occurs in postpartum mothers in the first week to one month. The data were collected by questionnaire. The measurement scale was continuous.

Age was maternal age during the interview based on the criteria for the date of birth and year of birth. The data were collected by questionnaire. The measurement scale was continuous.

Parity was the number of children born by the mother. The data were collected by questionnaire. The measurement scale was continuous.

Unwanted pregnancy was a pregnancy that was not desired by the subject of this study. The measuring instrument used is a questionnaire. The measurement scale was categorical.

Education was highest formal education attained by the mother. The data were collected by questionnaire. The measurement scale was categorical.

The type of labor was the result of the diagnosis of labor in the subject of this latest study. The data were collected by questionnaire. The measurement scale was categorical.

Psychological stress was a condition experienced by mothers when there was a discrepancy between the demands received and the ability to overcome them. The data were collected by questionnaire. The measurement scale was continuous. 
Journal of Maternal and Child Health (2019), 4(5): 358-368

https://doi.org/10.26911/thejmch.2019.04.05.10

Family support was the support of the family in the form of material and nonmaterial when the study subjects were in pregnancy. The data were collected by questionnaire. The measurement scale was continuous.

Income was the amount of income from the head of the family and the income of the mother in both permanent and additional work in a month which measured in rupiah with the minimum wage of Bantul Regency. The data were collected by questionnaire. The measurement scale was continuous.

Domestic violence was a treatment that was not desired by study subject, both in the form of physical, psychological, sexual, and economic violence. The data were collected by questionnaire. The measurement scale was categorical.

Frequency of antenatal care was the number of times the subject comes to health services both government and private to carry out prenatal checks conducted by health personnels. The data were collected by questionnaire. The measurement scale was continuous.

The number of families was the number of people who live together in one house because of the bond of marriage and birth which consists of the head of the family and family members. The data were collected by questionnaire. The measurement scale was continuous.

\section{e. Study Instrument}

The study instrument used for data collection was a questionnaire. Instrument has been tested for content validity and face validity and reliability test if the total item correlation value was $>0.20$ and alpha $(\alpha)$ chronbach $>0.06$.

\section{f. Data Analysis}

Univariate analysis to see frequency distribution and percentage of sample characteristics. Bivariate analysis with Chi-square test and multivariate analysis with path analysis with the following steps: model specifications, model identification, model suitability, parameter estimation, and model specification.

\section{g. Research Ethics}

Research ethics in this study include approval sheets, anonymity, confidentiality, and ethical research. Ethical feasibility in this study came from the Health Research Ethics Committee of Dr. Hospital. Moewardi Surakarta with number: 298/ III / HREC / 2019.

$\frac{\text { RESULTS }}{\text { 1. Characteristics Sample }}$
The sample characteristics was described in
Table 1.

Table 1. Characteristics sample (continuous data)

\begin{tabular}{lccccc}
\hline Variables & N & Mean & SD & Min & Max \\
\hline Postpartum Depression & 210 & 7.9 & 6.5 & 0.0 & 22 \\
Family Support & 210 & 0.6 & 0.2 & 0.2 & 0.9 \\
Domestic Violence & 210 & 0.4 & 0.2 & 0.1 & 0.8 \\
Psychological Stress & 210 & 20.4 & 8.6 & 10.0 & 48 \\
Age & 210 & 30.1 & 4.9 & 19.0 & 44 \\
Number of Antenatal care & 210 & 8.9 & 4.7 & 1.0 & 16 \\
Number of Family & 210 & 3.7 & 0.8 & 3.0 & 6 \\
Parity & 210 & 1.7 & 0.8 & 1.0 & 4 \\
\hline
\end{tabular}


Table 2. Characteristics sample (categorical data)

\begin{tabular}{|c|c|c|}
\hline Characteristics & $\mathbf{N}$ & Percentage \\
\hline \multicolumn{3}{|l|}{ Age } \\
\hline$<35$ years old & 123 & 58.6 \\
\hline$\geq 35$ years old & 87 & 41.4 \\
\hline \multicolumn{3}{|l|}{ Education } \\
\hline$<\mathrm{HS}$ & 82 & 39 \\
\hline$\geq \mathrm{HS}$ & 128 & 61 \\
\hline \multicolumn{3}{|l|}{ Income } \\
\hline Low & 89 & 42.4 \\
\hline High & 121 & 57.6 \\
\hline \multicolumn{3}{|c|}{ Number of Antenatal Care } \\
\hline$<4$ times & 74 & 35.2 \\
\hline$\geq 4$ times & 135 & 64.3 \\
\hline \multicolumn{3}{|l|}{ Number of Family } \\
\hline$<5$ people & 123 & 58.6 \\
\hline$\geq 5$ people & 87 & 41.4 \\
\hline \multicolumn{3}{|l|}{ Parity } \\
\hline Primipara & 86 & 41 \\
\hline Multipara & 124 & 59 \\
\hline \multicolumn{3}{|l|}{ Unwanted Pregnancy } \\
\hline Yes & 117 & $55 \cdot 7$ \\
\hline No & 93 & 44.3 \\
\hline \multicolumn{3}{|l|}{ Type of Labor } \\
\hline Normal & 112 & $53 \cdot 3$ \\
\hline Complication & 98 & 46.7 \\
\hline \multicolumn{3}{|l|}{ Family Support } \\
\hline Weak & 71 & 33.8 \\
\hline Strong & 139 & 66.2 \\
\hline \multicolumn{3}{|l|}{ Domestic Violence } \\
\hline Non DV & 156 & $74 \cdot 3$ \\
\hline DV & 54 & $25 \cdot 7$ \\
\hline \multicolumn{3}{|l|}{ Psychological Stress } \\
\hline Not experience stress & 120 & 57.1 \\
\hline Psychological stress & 90 & 42.9 \\
\hline \multicolumn{3}{|l|}{ Pospartum Depression } \\
\hline Not experience depression & 130 & 61.9 \\
\hline Postpartum depression & 80 & 38.1 \\
\hline
\end{tabular}

\section{Bivariate Analysis}

Table 3 showed the results of bivariate analysis of factors that influence postpartum depression. Table 2 showed that age $>35$ years old (OR $=0.12 ; \mathrm{p}<0.001)$, high school education $(\mathrm{OR}=0.03 ; \mathrm{p}$ $<0.001)$, Income $>\operatorname{Rp} 1,527,150(\mathrm{OR}=0.02$; $\mathrm{p}<0.001$ ), total antenatal care of $\geq 4$ times
$(\mathrm{OR}=0.03 ; \mathrm{p}=0.001)$, number of families $\geq 5$ people $(\mathrm{OR}=7.45 ; \mathrm{p}<0.001)$, parity $(\mathrm{OR}=5.85 ; \mathrm{p}<0.001)$, unwanted pregnancy $(\mathrm{OR}=182.8 ; \mathrm{p}<0.001)$, type of labor $(\mathrm{OR}=$ 43.8; $\mathrm{p}<0.001)$, family support $(\mathrm{OR}=0.07$; $\mathrm{p}<0.001)$, domestic violence $(\mathrm{OR}=25 ; \mathrm{p}$ $<0.001)$, and psychological stress $(\mathrm{OR}=115$; $\mathrm{p}<0.001)$. 
Journal of Maternal and Child Health (2019), 4(5): 358-368

https://doi.org/10.26911/thejmch.2019.04.05.10

Table 3. The results of bivariate analysis

\begin{tabular}{|c|c|c|c|c|c|c|c|c|}
\hline \multirow{3}{*}{$\begin{array}{l}\text { Independent } \\
\text { Variables }\end{array}$} & \multicolumn{4}{|c|}{ Postpartum Depression } & \multirow{2}{*}{\multicolumn{2}{|c|}{ Total }} & \multirow{3}{*}{ OR } & \multirow{3}{*}{$\mathbf{p}$} \\
\hline & \multicolumn{2}{|c|}{ Not depressed } & \multicolumn{2}{|c|}{ Depressed } & & & & \\
\hline & $\mathbf{N}$ & $\%$ & $\mathbf{N}$ & $\%$ & $\mathbf{N}$ & $\%$ & & \\
\hline \multicolumn{9}{|l|}{ Age } \\
\hline$<35$ years old & 54 & 44.3 & 68 & $55 \cdot 7$ & 123 & 100 & 0.12 & $<0.001$ \\
\hline$\geq 35$ years old & 76 & 86.4 & 12 & 13.6 & 87 & 100 & & \\
\hline \multicolumn{9}{|l|}{ Education } \\
\hline$<$ Senior high school & 16 & 19.5 & 66 & 80.5 & 82 & 100 & 0.03 & $<0.001$ \\
\hline$\geq$ Senior high school & 114 & 89.1 & 14 & 10.9 & 128 & 100 & & \\
\hline \multicolumn{9}{|l|}{ Income } \\
\hline Low $(<\operatorname{Rp} 1,527,150)$ & 18 & 20.2 & 71 & 79.8 & 89 & 100 & 0.02 & $<0.001$ \\
\hline High ( $\geq$ Rp 1,527,150) & 112 & 92.6 & 9 & 7.4 & 121 & 100 & & \\
\hline \multicolumn{9}{|l|}{ Number ANC } \\
\hline$<4$ times & 12 & 16.2 & 62 & 83.8 & 74 & 100 & 0.03 & $<0.001$ \\
\hline$\geq 4$ times & 118 & 86.8 & 18 & 13.2 & 135 & 100 & & \\
\hline \multicolumn{9}{|l|}{ Number of Family } \\
\hline$<5$ people & 99 & 80.5 & 24 & 19.5 & 123 & 100 & 7.45 & $<0.001$ \\
\hline$\geq 5$ people & 31 & 35.6 & 56 & 64.4 & 87 & 100 & & \\
\hline \multicolumn{9}{|l|}{ Parity } \\
\hline Primiparous & 72 & 83.7 & 14 & 16.3 & 86 & 100 & 5.85 & $<0.001$ \\
\hline Multiparous & 58 & 46.8 & 66 & 53.2 & 124 & 100 & & \\
\hline \multicolumn{9}{|l|}{ Unwanted } \\
\hline \multicolumn{9}{|l|}{ Pregnancy } \\
\hline Yes & 114 & 97.4 & 3 & 2.6 & 117 & 100 & 182. & $<0.001$ \\
\hline No & 16 & 17.2 & 77 & 82.8 & 93 & 100 & & \\
\hline \multicolumn{9}{|l|}{ Type of Labor } \\
\hline Normal & 105 & 93.8 & 7 & 6.2 & 112 & 100 & 43.8 & $<0.001$ \\
\hline Complication & 25 & 25.5 & 73 & 74.5 & 98 & 100 & & \\
\hline \multicolumn{9}{|l|}{ Family Support } \\
\hline Weak & 17 & 23.9 & 54 & 76.1 & 71 & 100 & 0.07 & $<0.001$ \\
\hline Strong & 113 & 81.3 & 26 & 18.7 & 139 & 100 & & \\
\hline \multicolumn{9}{|l|}{ Domestic Violence } \\
\hline No & 123 & 78.8 & 33 & 21.2 & 156 & 100 & 25 & $<0.001$ \\
\hline Yes & 7 & 13.0 & 47 & 87.0 & 54 & 100 & & \\
\hline \multicolumn{9}{|l|}{ Psychological Stress } \\
\hline No & 115 & 95.8 & 5 & 4.2 & 120 & 100 & 115 & $<0.001$ \\
\hline Yes & 15 & 16.7 & 75 & 83.3 & 90 & 100 & & \\
\hline
\end{tabular}

\section{Path Analysis}

\section{a. Model Specification}

Model specifications were used to describe the variables to be studied. The variables in this study consisted of age, education, income, income, number of antenatal care, number of families, parity, unwanted pregnancy, type of labor, family support, domestic violence, and psychological stress.

\section{b. Model Identification}

Measured variables include:

1) Total of measured variable : 12
2) Endogenous variables : 7

3) Exogenous variables :5

Degree of freedom (df) is as follows:

$\mathrm{df}=$ (number of measured variables $\mathrm{x}$ (number of measured variables +1 ) / 2 - (endogenous variables + exogenous variables + number of parameters) )

$=(12 \times(12+1) / 2-(7+5+12)$

$=(156 / 2)-24$

$=78-24=54$

The result of $\mathrm{df}$ was 54 which mean that over identified or path analysis can be done. 


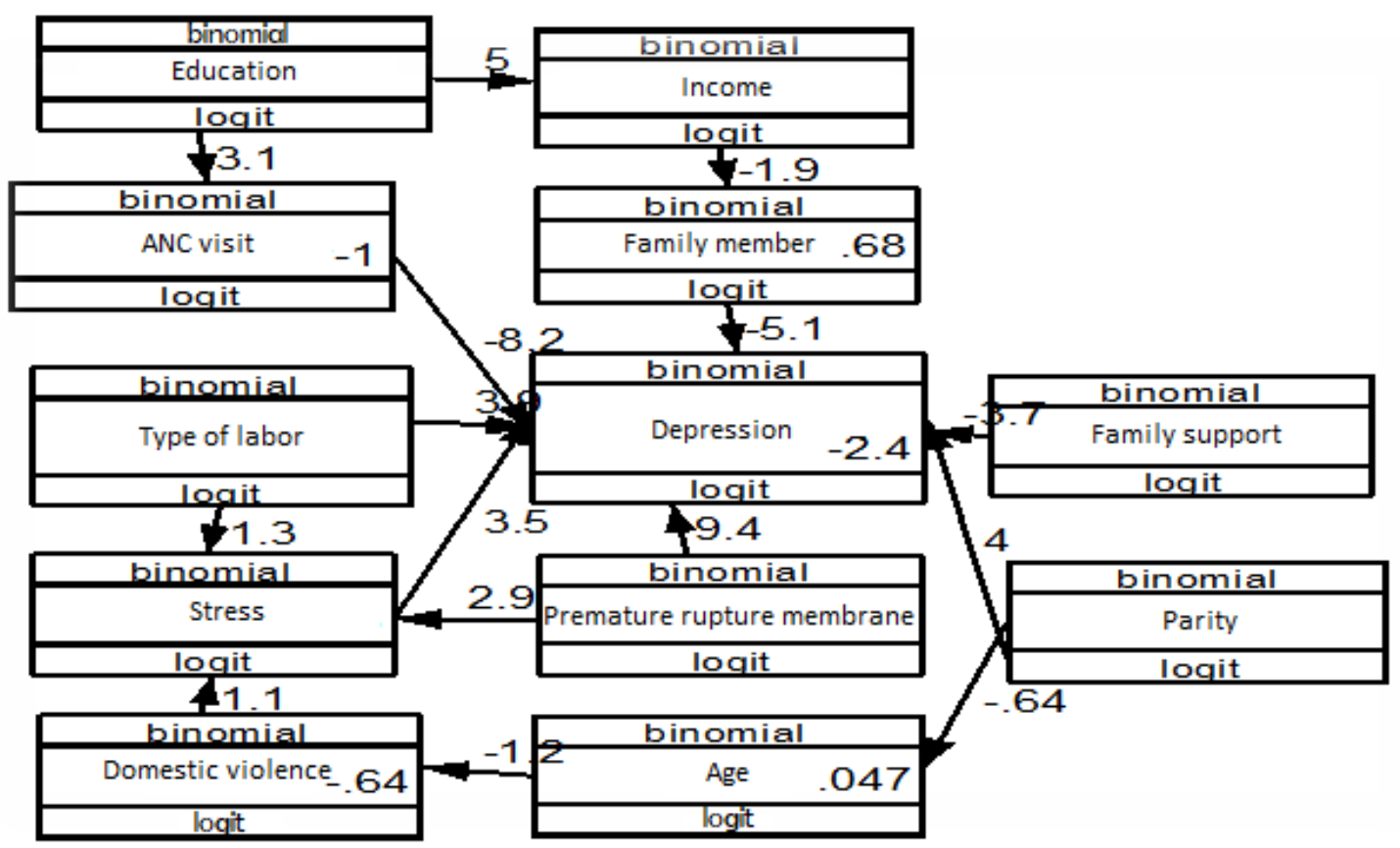

Figure 1. Structural model of path analysis with estimation

Table 4. The results of the path analysis

\begin{tabular}{|c|c|c|c|c|c|c|}
\hline \multirow[b]{2}{*}{$\begin{array}{l}\text { Dependent } \\
\text { Variables }\end{array}$} & \multirow{2}{*}{\multicolumn{2}{|c|}{ Independent Variables }} & \multirow[b]{2}{*}{ b } & \multicolumn{2}{|c|}{$95 \% \mathrm{CI}$} & \multirow[b]{2}{*}{$\mathbf{p}$} \\
\hline & & & & $\begin{array}{c}\text { Lower } \\
\text { Limit }\end{array}$ & $\begin{array}{l}\text { Upper } \\
\text { Limit }\end{array}$ & \\
\hline \multicolumn{7}{|l|}{ Direct Effect } \\
\hline Postpartum & & Number of family ( $\geq 5$ people) & -5.05 & -10.0 & -0.02 & 0.049 \\
\hline \multirow[t]{6}{*}{ Depression } & & Family support (strong) & -3.73 & -6.98 & -0.50 & 0.024 \\
\hline & & Number of ANC $(\geq 4)$ & -8.18 & $-15 \cdot 3$ & -1.00 & 0.026 \\
\hline & & Kind of labor (complication) & 3.85 & 0.16 & 7.54 & 0.041 \\
\hline & & Psychological stress & 3.53 & 0.34 & 6.72 & 0.030 \\
\hline & & Parity & 4.01 & 0.04 & 7.98 & 0.048 \\
\hline & & Unwanted pregnancy & 9.43 & 1.51 & 17.3 & 0.019 \\
\hline \multicolumn{7}{|l|}{ Indirect Effect } \\
\hline Income & & Education ( $\geq$ senior high school) & 5.00 & 3.92 & 6.08 & $<0.001$ \\
\hline $\begin{array}{l}\text { Number of ANC } \\
\text { visit }\end{array}$ & & Education ( $\geq$ senior high school) & 3.10 & 2.36 & 3.83 & $<0.001$ \\
\hline Number of family & & High income & -1.87 & -2.48 & -1.26 & $<0.001$ \\
\hline \multirow[t]{3}{*}{$\begin{array}{l}\text { Psychological } \\
\text { stress }\end{array}$} & & $\begin{array}{l}\text { Type of labor (with } \\
\text { complication) }\end{array}$ & 1.27 & 0.36 & 2.17 & 0.006 \\
\hline & & Domestic violence & 1.05 & -0.04 & 2.14 & 0.059 \\
\hline & $\leftarrow$ & Unwanted pregnancy & 2.85 & 1.99 & 3.70 & $<0.001$ \\
\hline Age & & Parity & -0.64 & -1.20 & -0.83 & 0.024 \\
\hline $\begin{array}{l}\text { Domestic } \\
\text { violence }\end{array}$ & & Age $(\geq 35$ years old $)$ & -1.20 & -1.91 & -0.48 & 0.001 \\
\hline \multicolumn{7}{|c|}{$\mathrm{N}$ Observation $=210$} \\
\hline \multicolumn{7}{|c|}{ Log likehood $=-611.870$} \\
\hline \multicolumn{7}{|c|}{$\mathrm{AIC}=1267.7$} \\
\hline $\mathrm{BIC}=1341.3$ & & & & & & \\
\hline
\end{tabular}




\section{DISCUSSION \\ 1. The Effect of Age on Postpartum Depression}

This study showed that maternal age has an indirect influence on the incidence of postpartum depression through domestic violence. The effect of age on domestic violence was negative and statistically significant.

Young mothers ( $<35$ years old) were more likely to experience domestic violence because they have not been able to make good decisions so that the husband dominated the family, this can indirectly encourage the occurrence of domestic violence. The existence of domestic violence in the household can cause the mother to experience psychological stress, if this was left continuously without any treatment, the mother would experience postpartum depression.

The results of the analysis also showed the effect of age on the incidence of postpartum depression through psychological stress. The influence was negative and statistically significant. Older mothers $(\geq 35$ years old) this was because old age already has physical and mental resources and experience, so it influenced their coping mechanism. A mother with age has enough experience so that she can take care of her child better and can manage psychological stress well so that it was less likely to experience psychological stress which can lead to the incidence of postpartum depression.

This study were in accordance with a study by Kusuma (2017) which stated that of the 34 respondents of primiparous mothers, respondents who had a higher risk of postpartum depression compared with respondents who did not have the risk of postpartum depression. Most age-based postpartum depression was in the productive age group (21-35 years old) who were 16 people (47.1\%) (Kusuma, 2017).
This study was in line with Ria et al. (2015) which found that young people $(<35$ years old) had a risk for postpartum depression by 52 people (53.2\%) compared to older people ( $\geq 35$ years old) from 150 samples.

\section{The Effect of Education on Post- partum Depression}

This study showed that maternal education had an indirect and positive influence with postpartum depression through income and the amount of antenatal care. The influence was statistically significant. The results of this study indicated that mothers with education $\geq$ HS would get better employment opportunities. The higher the maternal income, the smaller the chance of experiencing postpartum depression.

Stepanikova et al. (2017), who stated that women with low levels of education would increase their risk of depression after labor. Low education was an indicator of someone in terms of socio-economic status, mothers with low education would have difficulty in getting quality jobs (Kim,2018).

\section{The Effect of Income on Post- partum Depression}

This study indicated that there was indirect and negative effect between income and the incidence of postpartum depression through the number of families. The influence was statistically significant. The higher the income of the mother and family, the less likely it was to experience postpartum depression.

Economy or income was always one of the determining factors in a healthy pregnancy process. Family income was a crucial thing that can affect a person's health. Mother and family with high economy can check their pregnancy regularly, plan delivery at health staff, check the health of the mother and baby after birth, and make other preparations well. Whereas mothers and families with low economies would 
experience difficulties in fulfilling their daily needs which can be a concern for mothers so as to influence maternal psychological factors that have an impact on the occurrence of postpartum depression.

The results of this study were in line with Holland et al. (2011) which stated that many young women with very low income were found to live in one family with their parents. Jannah et al. (2019) stated that postpartum mothers who have high income reduce the risk of postpartum depression by 2.28 units higher compared to postpartum mothers with low income.

\section{The Effect of Number of ANC on Postpartum Depression}

The results of the analysis in this study indicated that there was a direct and negative influence on the number of antenatal care and the incidence of postpartum depression and the effect was statistically significant. The results of this study indicated that a mother with a number of antenatal care $\geq 4$ times would directly influence the incidence of postpartum depression compared to women who conduct antenatal care by $<4$ times.

This study showed that there was a relationship between the number of ANC visits and the incidence of postpartum depression. Antenatal services according to standards were services provided to pregnant women at least 4 times during a one-time pregnancy schedule in the first trimester, once in the second trimester and twice in the third trimester (Ministry of Health, 2016).

\section{The Effect of Number of Family on Postpartum Depression}

The results of the analysis in this study indicated that there was a direct and negative influence on the number of families with postpartum depression incident and the effect was statistically significant. The results of this study indicated that a mother whose number of families $\geq 5$ people were less likely to experience postpartum depression than mothers with number of family $<5$ people.

The results of this study are in line with Tambelli et al. (2015) which stated that family involvement was important to support the handling of postpartum depression. Stress in a single parent was related to the financial aspects and economic situation which can then influence the health condition of himself and his family.

\section{The Effect of Parity on Postpartum Depression}

The results of the analysis in this study indicated that there was a direct and positive influence on parity with postpartum depression incident and the effect was statistically significant. The results of this study indicate that a multiparous mother was more likely to experience postpartum depression than primiparous mothers.

The result of this study was in line with Kim (2018) which explained that if mothers have more than one child aged $<2$ years old, the birth of a second child might be a greater burden on the family and affect their mental health status.

\section{The Effect of Unwanted Pregnancy on Postpartum Depression}

The results of the analysis in this study showed that there was direct and positive effect of unwanted pregnancies on psychological stress and postpartum depression, the effect was statistically significant. The results of this study indicated that a woman who experienced unwanted pregnancy has a greater risk of experiencing psychological stress and the incidence of postpartum depression than the woman who wanted her pregnancy.

This study was in line with Putriarsih et al. (2018) which related to the prevalence and determinants of postpartum depression with a questionnaire measuring tool cover- 
ing several aspects, one of them was the aspect of unwanted pregnancy which was o.30 times more likely to experience postpartum depression.

\section{The Effect of Type of Labor on Postpartum Depression}

The results of the analysis in this study indicated that there was a direct and positive influence on the type of labor on psychological stress and postpartum depression, the effect was statistically significant. The results of this study indicated that a mother who experiences labor with complications has a greater risk of experiencing psychological stress and the incidence of postpartum depression than a mother with normal labor.

This study were in line with Mathisen (2013), which explained that mothers tend to assume that labor with complications in such as caesarean section as a source of fear, stress, and trauma that affect maternal psychological stress which can lead to postpartum depression.

\section{The Effect of Family Support on Postpartum Depression}

The results of the analysis in this study indicated that there was a direct and negative influence on the number of family support with the incidence of postpartum depression and the effect was statistically significant. The results of this study indicated that a mother with a strong family support would directly influence the incidence of postpartum depression than mothers who got weak family support.

Family support was an emotional bond between family and people around them who care, care, give attention, help in the form of emotional support, information, instrumental, and appreciation for the mother in caring for her baby (Motzfeldt et al., 2013). This study were supported by a study done by Chang (2016) which showed that strong social support from husbands, families, friends, and people around mothers can improve psychological welfare. Support given by the husband to the wife during postpartum would foster the confidence of the mother to care for the baby.

This wan line with Kurniasari et al. (2015) which stated that postpartum mothers who did not receive husbands support were 6.01 times more likely to experience postpartum depression than postpartum mothers who got husbands support. The low support of husbands and families would increase the incidence of postpartum depression.

\section{The Effect of Domestic Violence on Postpartum Depression}

This study showed that there was indirect and positive effect of domestic violence on postpartum depression through psychological stress. The effect was statistically significant. The results of this study indicated that a mother who experienced domestic violence has a greater risk of experiencing the incidence of postpartum depression than mothers who did not experience domestic violence. A mother who experienced domestic violence caused the mother to experience physical and psychological disorders, including psychological stress that would affect the occurrence of postpartum depression.

Domestic violence was the abuse done by a partner to their spouse or vice versa, both in the form of physical, psychological, sexual, and economic violence. So that pain and trauma can occur. Overall coverage was better known because this often occurred in private spaces and generally, the victims did not report it because they feel embarrassed and afraid (Janiwarty and Pieter, 2013.)

\section{The Effect of Psychological Stress on Postpartum Depression}

The results of the analysis in this study indicated that there was a direct and 
positive effect ofpsychological stress on postpartum depression, the effect was statistically significant. The results of this study indicated that a mother who was psychologically stressed has a greater risk of experiencing postpartum depression than mothers who did not experience psychological stress.

This study was in line with the results of the study done by Ria et al. (2015) which stated that mothers who experienced psychological stress have a logit score of postpartum depression by 2.15 units higher than mothers who did not experience psychological stress.

\section{AUTHOR CONTRIBUTION}

Sri Widarti collected the data. Uki Retno Budihastuti examined the conceptual frame work and study method. Vitri Widyaningsih reviewed the paper.

\section{FUNDING AND SPONSORSHIP}

This study used independent costs by the authors.

\section{ACKNOWLEDGEMENT}

We thank to Bappeda Bantul for assistance the data collection and postpartum mothers in Yogyakarta who had participated and were willing to be the study subjects.

\section{CONFLICT OF INTEREST}

There is no conflict of interest in this study.

$\frac{\text { REFERENCE }}{\text { Chang FW, Lee WY, Liu YP, Yang JJ, Chen }}$

SP, Cheng KC, Liu JM (2016). The relationship between economic conditions and postpartum depression in Taiwan: A nationwide population based study. Journal of Affective Disorders, 20(4): 174-179. https://doi.org/10.1016/j.jad.2016.06.43
Habel C, Feeley N, Hayton B, Bell L, (2016). Causes of women's postpartum depression symptoms. Men's and women perceptions. Midwefery, 31(7): 728-734. https://doi.org/10.1016/j.midw.2015.03.007

Holland ML, Yoo, BK, Kitzman H, Chaudron L, Szilagyi PG,Temkin-GreenerH (2011) Self-efficacy as a mediator between maternal depression and child hospitalizations in low-income urban families. Maternal and Child Health Journal. 15(7): 1011-1019. https://doi.org/10.1007/s10995-010-0662-Z

Janiwarty B, Pieter HZ. (2013) Pendidikan Psikologi untuk Bidan Suatu Teori dan Terapannya. Yogyakarta: andyoffset.

Jannah AM, Budihastuti UR, Murti B (2019). Contextual effect of place of birth delivery on depression in Karanganyar, Central Java. Journal of Maternal and Child Health, 4(3): 212221.https://doi.org/10.26911/thejmch .2019.04.03.08

Kemenkes (2016). Peraturan Menteri Kesehatan RI No.43 Tahun 2016 tentang Standar Pelayanan Minimal Bidang Kesehatan. 79.

Kim Y, Dee V (2018). Sociodemographic and obstetric factors related to symptoms of postpartum depression in hispanic women in rural California. Journal of Obstetric, Gynecologic, and Neonatal Nursing, 47(1): 23-31. https://doi.org/10.1016/j.jogn.2017.11.012.

Kurniasari D, Astuti YA (2015). Hubungan antara karakteristik ibu, kondisi bayi dan dukungan sosial suami dengan postpartum blues pada ibu dengan persalinan SC di Rumah Sakit Umum Ahmd Yani Metro Tahun 2014. Jurnal Kesehatan Holistik, 9(3): 115-125. Retrieved from http://ejurnalmalahayati.ac.id/index.php/holistik/article /view/215/154. 
Kusuma PD (2017). Karakteristik penyebab terjadinya depresi postpartum pada primipara dan multipara. Jurnal Keperawatan Notokusumo, 5(1): 36-45.

Manley G (2013). Public Access NIH Public Access. 27(1), 1-15. https://doi.org/10.1038/mp.2011.182.doi.

Mathisen SE, Glavin K, Lien Lagerlove P, (2013). Prevalence and risk factors for postpartum depressive symptoms in Argentina: a cross-sectional study. International Journal of Women's Health. http://dx.doi.org/10.2147/IJWH.S51436.

Motzfeldt I, AndreasenS, Pedersen AL, Pedersen ML, (2013). Prevalence of postpartum depression in Nuuk, Green land- A cross-sectional study using Edinburgh Postnatal Depression Scale. International Journal of Circumpolar Health 72(1): 1-6. https://doi.org/10.3402/ijch.v72io.21114.

Organization World Health (2013). WHO recommendations on postnatal care of the mother and newborn.

Putriarsih R, Budihastuti UR, Murti B (2018). Prevalence and determinants of postpartum depression in Sukoharjo District, Central Java. Journal of Maternal and Child Health, 3(1): 395408. https://doi.org/10.26911/thejmch.2017.03.01.02.

Qobadi M, Collier C, Zhang L (2016). The effect of stressful life events on postpartum depression: Findings from the 2009-2011 Mississippi pregnancy risk assessment monitoring system. Ma- ternal and Child Health Journal, 20(1): 164-172. https://doi.org/10.1007/s10995-016-2028-7.

Ria MB, Budihastuti UR, Subiyanto, A (2015). Risk factors of postpartum depression at Dr. Moewardi Hospital, Surakarta. Journal of Maternal and Child Health.3(1):81-9o.https://doi.org/10.26911/thejmch.2018.03.01.08

Stepanikova I, Kukla L (2017). Is perceived discrimination in pregnancy prospectively linked to postpartum depression? Exploring the Role of Education. Maternal and Child Health Journal, 21(8): 1669-1677. https://doi.org/10.1007/s10995-016-2259-7.

Sylvén SM, Thomopoulos TP, Kollia N, Jonsson M, Skalkidou A (2017). Correlates of postpartum depression in first time mothers without previous psychiatric contact. Eur Psychiatry, 40: 4-12. Retrieved from https://reference.medscape.com/medline/abstract/27837672

Tambelli R, Cerniglia L, Cimino S, Ballarotto G (2015). Parent-infant interactions in families with women diagnosed with postnatal depression: a longitudinal study on the effects of a psychodynamic treatment. 6(1210):1-8 https://doi.org/10.3389/fpsyg.2015.0 1210

Tikmani SS, Soomro T, Tikmani P, Zulfiqar S, Bhutto A (2016). Prevalence and determinants of postpartum depression in a Tertiary Care Hospital. Austin J Obstet Gynecol. 3(2): 0-4. 